NATIONAL LABORATORY

\title{
NGNP Graphite Selection and Acquisition Strategy
}

September 2007

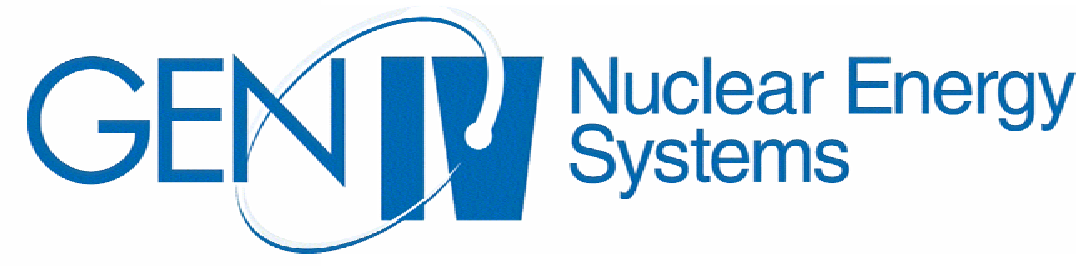

Prepared by

T. Burchell

R. Bratton

W. Windes

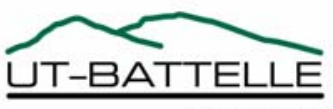




\title{
DOCUMENT AVAILABILITY
}

Reports produced after January 1, 1996, are generally available free via the U.S. Department of Energy (DOE) Information Bridge.

Web site http://www.osti.gov/bridge

Reports produced before January 1, 1996, may be purchased by members of the public from the following source.

\author{
National Technical Information Service \\ 5285 Port Royal Road \\ Springfield, VA 22161 \\ Telephone 703-605-6000 (1-800-553-6847) \\ TDD 703-487-4639 \\ Fax 703-605-6900 \\ E-mail info@ntis.gov \\ Web site http://www.ntis.gov/support/ordernowabout.htm
}

Reports are available to DOE employees, DOE contractors, Energy Technology Data Exchange (ETDE) representatives, and International Nuclear Information System (INIS) representatives from the following source.

Office of Scientific and Technical Information

P.O. Box 62

Oak Ridge, TN 37831

Telephone 865-576-8401

Fax 865-576-5728

E-mail reports@osti.gov

Web site http://www.osti.gov/contact.html

This report was prepared as an account of work sponsored by an agency of the United States Government. Neither the United States government nor any agency thereof, nor any of their employees, makes any warranty, express or implied, or assumes any legal liability or responsibility for the accuracy, completeness, or usefulness of any information, apparatus, product, or process disclosed, or represents that its use would not infringe privately owned rights. Reference herein to any specific commercial product, process, or service by trade name, trademark, manufacturer, or otherwise, does not necessarily constitute or imply its endorsement, recommendation, or favoring by the United States Government or any agency thereof. The views and opinions of authors expressed herein do not necessarily state or reflect those of the United States Government or any agency thereof. 
Materials Science and Technology Division

\title{
NGNP GRAPHITE SELECTION AND ACQUISITION STRATEGY
}

\author{
T. Burchell* \\ R. Bratton ${ }^{\dagger}$ \\ W. Windes ${ }^{\dagger}$
}

*Oak Ridge National Laboratory

† Idaho National Laboratory

Prepared by OAK RIDGE NATIONAL LABORATORY

Oak Ridge, Tennessee 37831-6283

managed by

UT-BATTELLE, LLC

for the

U.S. DEPARTMENT OF ENERGY

under contract DE-AC05-00OR22725 



\section{CONTENTS}

Page

LIST OF FIGURES

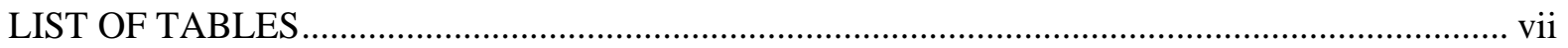

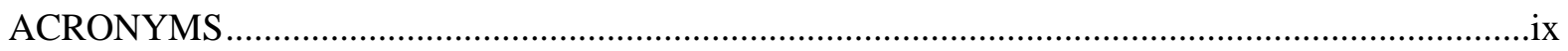

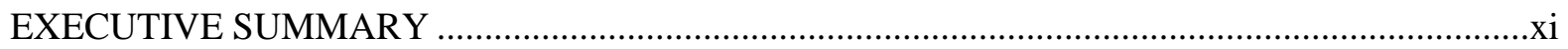

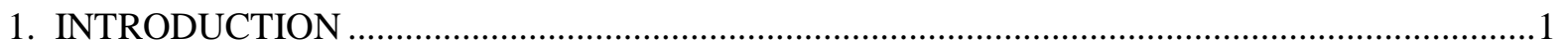

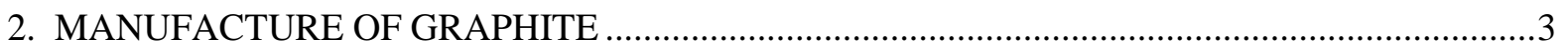

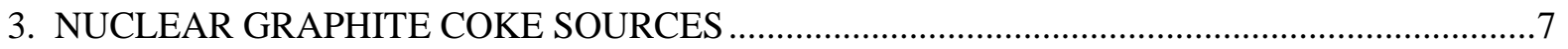

4. EXISTING CANDIDATE NUCLEAR GRAPHITE GRADES …............................................

5. FACTORS INFLUENCING GRAPHITE SECTION FOR THE NGNP .....................................

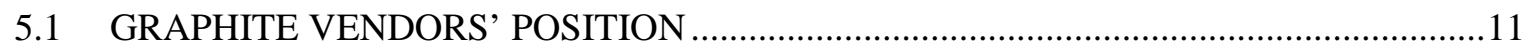

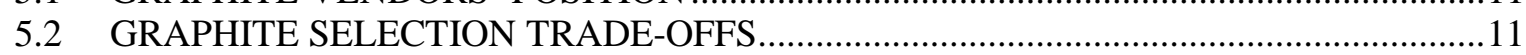

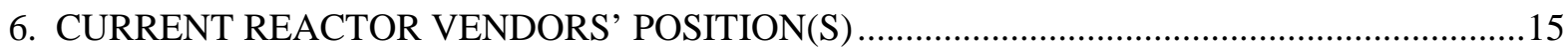

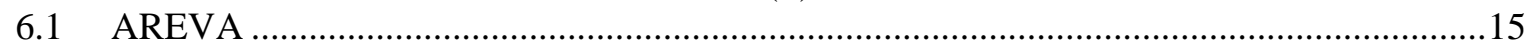

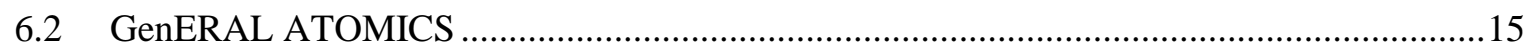

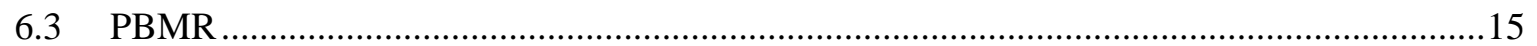

7. RECOMMENDED NGNP GRAPHITE SELECTION AND ACQUISITION STRATEGY.........17

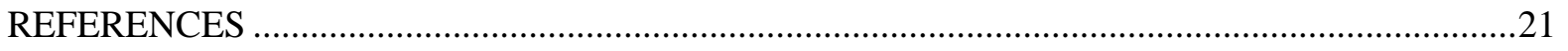





\section{LIST OF FIGURES}

Figure

Page

$1 \quad$ The process steps in the manufacture of nuclear graphite ............................................. 3

$2 \quad$ HTTR graphite reflector block undergoing machining ..............................................

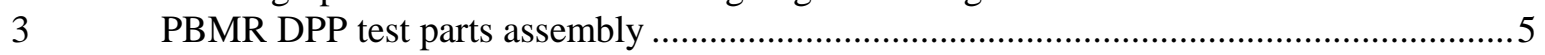





\section{LIST OF TABLES}

\section{Table}

Page

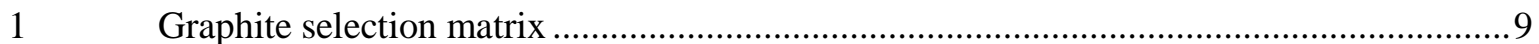

$2 \quad$ Candidate Carbone of America graphite grades........................................................ 15

3 Graphites recommended for inclusion in the NGNP Graphite Technology

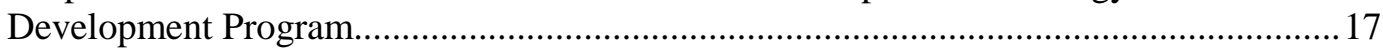

4 Graphite strategy advantages and disadvantages for each reactor vendor's NGNP

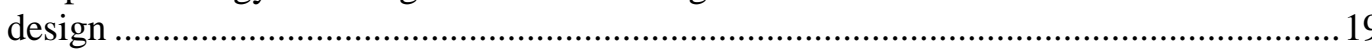





\section{ACRONYMS}

$\begin{array}{ll}\text { ASME } & \text { American Society of Mechanical Engineers } \\ \text { CTE } & \text { coefficient of thermal expansion } \\ \text { DPP } & \text { demonstration power plant } \\ \text { EU } & \text { European Union } \\ \text { GA } & \text { General Atomics } \\ \text { HTR } & \text { High-Temperature Reactor } \\ \text { HTTR } & \text { High-Temperature Test Reactor } \\ \text { JAEA } & \text { Japan Atomic Energy Agency } \\ \text { NGNP } & \text { Next-Generation Nuclear Plant } \\ \text { PBMR } & \text { pebble bed modular reactor } \\ \text { pet } & \text { petroleum } \\ \text { PIRT } & \text { Phenomena Identification and Ranking Table } \\ \text { QA } & \text { quality assurance } \\ \text { TDP } & \text { Technology Development Program } \\ \text { U.K. } & \text { United Kingdom } \\ \text { U.S. } & \text { United States } \\ \text { VHTR } & \text { very high-temperature reactor } \\ \text { WV } & \text { West Virginia }\end{array}$





\section{EXECUTIVE SUMMARY}

This report describes the Next-Generation Nuclear Plant (NGNP) graphite selection and acquisition strategy. The strategy is based upon inputs from all NGNP reactor vendors and nuclear graphite manufacturers. This document supersedes the previously published graphite selection strategy. ${ }^{1}$ It is recommended that the following six candidate graphites (from four manufacturers) should be included in the NGNP Graphite Technology Development Program (TDP).

\begin{tabular}{|c|c|c|c|}
\hline Grade & Manufacturer & Coke type & Comments \\
\hline IG-430 & Toyo Tanso & Pitch coke & $\begin{array}{l}\text { Isostatically molded, candidate for high- } \\
\text { dose regions of NGNP concepts }\end{array}$ \\
\hline NBG-17 & SGL & Pitch coke & $\begin{array}{l}\text { Vibrationally molded, candidate for } \\
\text { high-dose regions of NGNP prismatic } \\
\text { core concepts (not currently } \\
\text { commercially available) }\end{array}$ \\
\hline NBG-18 & SGL & Pitch coke & $\begin{array}{l}\text { Vibrationally molded, candidate for } \\
\text { high-dose regions of NGNP pebble bed } \\
\text { concepts; PBMR reflector graphite }\end{array}$ \\
\hline PCEA & GrafTech International & Petroleum coke & $\begin{array}{l}\text { Extruded, candidate for high-dose } \\
\text { regions of NGNP prismatic core } \\
\text { concepts }\end{array}$ \\
\hline PGX & GrafTech International & Petroleum coke & $\begin{array}{l}\text { Large blocks for permanent structure in } \\
\text { a prismatic core (used in HTTR) }\end{array}$ \\
\hline 2020 & Carbone of America & Petroleum coke & $\begin{array}{l}\text { Isostatically molded, candidate for } \\
\text { permanent structures in a prismatic } \\
\text { core }\end{array}$ \\
\hline
\end{tabular}

From the six candidates above, two grades, GrafTech International PCEA and SGL NGB-18 should be considered as the major candidates for the purposes of the graphite TDP. These two grades are capable of meeting all NGNP needs, although they may not be a particular vendor's preferred graphite. It is further recommended that the NGNP project consider two longer term options: (1) the development of an alternate isotropic coke source, and (2) the potential for the "recycling" of graphite as an alternative to long-term repository disposal.

In summary, the following actions are strongly recommended:

- qualify two graphite vendors (SGL \& GrafTech International) to NQA-1,

- purchase production lots of PCEA and NBG-18 from above vendors,

- begin characterization of the properties of the above two major candidate grades,

- continue irradiation experiments with two major graphites (NBG-18 and PCEA) and other alternates (IG-430, NBG-17, 2020, and PGX) until more definition on the NGNP design and vendor is available, and

- pursue collaboration with international partners via Generation IV (Gen IV).

Furthermore, it is recommended that

- serious consideration be given to establishing alternative coke sources to the two currently available (U.S. pet coke and Japanese pitch coke), and

- explore graphite recycle and reuse options. 



\section{INTRODUCTION}

The nuclear graphite (H-451) previously used in the United States for High-Temperature Reactors (HTRs) is no longer available. New graphites have been developed and are considered suitable candidates for the Next-Generation Nuclear Plant (NGNP). A complete properties database for these new, available, candidate grades of graphite must be developed to support the design and licensing of NGNP core components. Data are required for the physical, mechanical (including radiation-induced creep), and oxidation properties of graphites. Moreover, the data must be statistically sound and take account of in-billet, between billets, and lot-to-lot variations of properties. These data are needed to support the ongoing development ${ }^{1}$ of the risk-derived American Society of Mechanical Engineers (ASME) graphite design code (a consensus code being prepared under the jurisdiction of the ASME by gas-cooled reactor and NGNP stakeholders including the vendors). The earlier Fort St. Vrain design of High-Temperature Reactor (HTRs) used deterministic performance models for H-451, while the NGNP will use new graphite grades and risk-derived (probabilistic) performance models and design codes, such as that being developed by the ASME. A radiation effects database must be developed for the currently available graphite materials, and this requires a substantial graphite irradiation program. The graphite Technology Development Plan (TDP $)^{2}$ describes the data needed and the experiments planned to acquire these data in a timely fashion to support NGNP design, construction, and licensing.

The strategy for the selection of appropriate grades of graphite for the NGNP is discussed here. The final selection of graphite grades depends upon the chosen reactor type and vendor because the reactor type (pebble bed or prismatic block) has a major influence on the graphite chosen by the designer. However, the time required to obtain the needed irradiation data for the selected NGNP graphite is sufficiently long that a preliminary selection was necessary in $2005 .{ }^{1}$ A further downselect was made in 2006, reducing the number of candidate graphites to two, with two reserve grades. Since then additional information has been obtained from potential NGNP vendors and graphite manufacturers. Therefore, the NGNP graphite selection strategy has been reassessed. New recommendations, and the rationale for these recommendations, are reported and discussed here. 



\section{MANUFACTURE OF GRAPHITE}

Graphite is a composite material manufactured from filler coke and pitch binder. Nuclear graphites are usually manufactured from isotropic cokes (petroleum or coal-tar derived) and are formed in a manner to make them near-isotropic or isotropic material. Figure 1 shows the major processing steps in the manufacturing of nuclear graphite. After baking (carbonization), the artifact is typically impregnated with a petroleum pitch and rebaked to densify the part. Impregnation and rebake may occur several times to attain the required density. Graphitization typically occurs at temperatures $>2500^{\circ} \mathrm{C}$. Additional halogen purification may be required. Typical manufacturing times for a lot of graphite are 6-9 months. ${ }^{3}$

The forming and densification processes impart property variations within the billet. The properties will be different in the forming direction compared with the perpendicular to forming direction. Moreover, a density gradient will exist from billet edge to center. These variations must be quantified for the selected grades of graphite. In addition, variations in properties will occur from billet to billet within a batch, and between production lots. In extruded graphite the in-billet variations

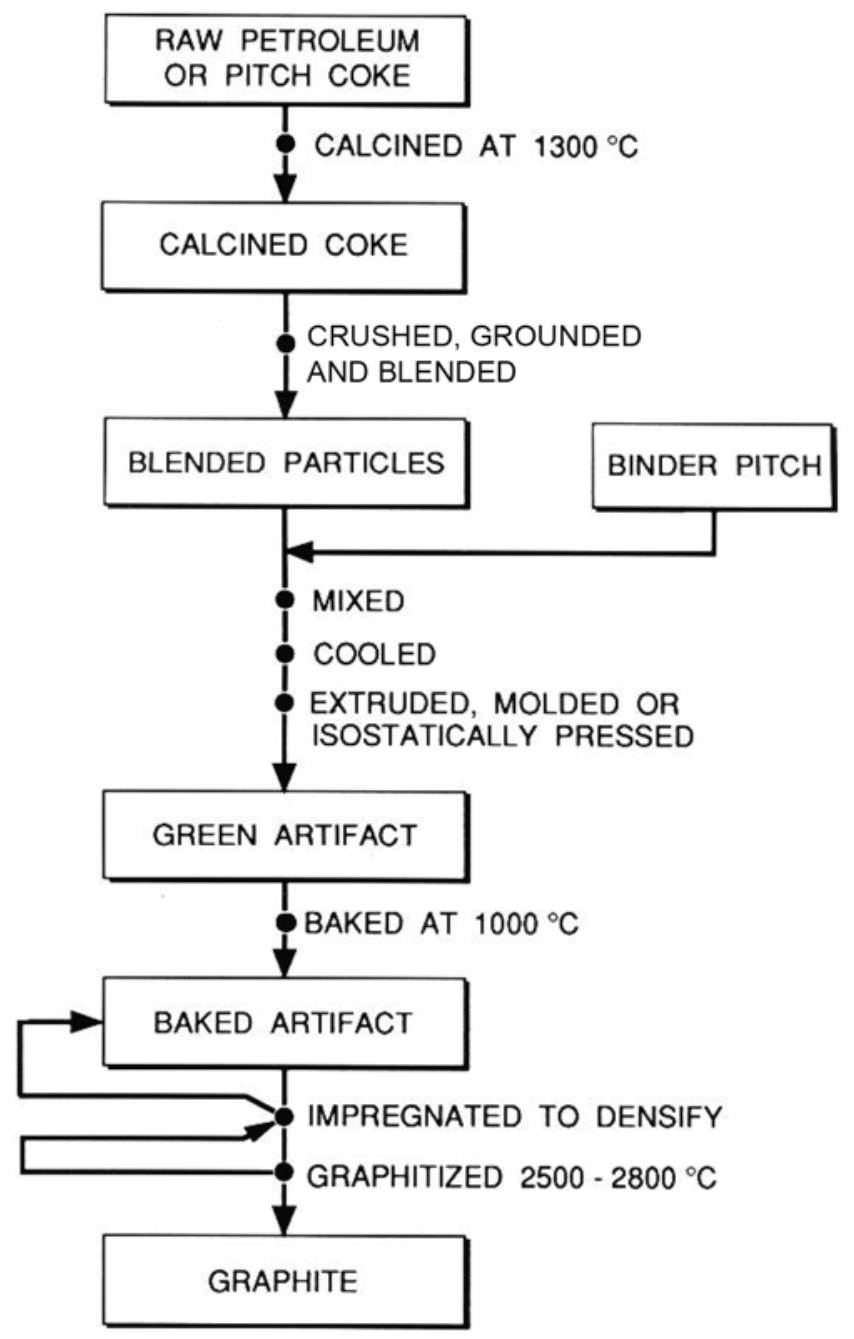

Fig. 1. The process steps in the manufacture of nuclear graphite. ${ }^{3}$ 
will be significant and can exceed the lot-to-lot variations. In isostatically molded graphite, the inbillet variations will be smaller than for extruded graphite and will be of the order of the lot-to-lot variations.

Finished graphite billets are machined to the complex geometries required for the reactor components (fuel elements, reflector blocks, core support post, etc.). Figure 2 shows a graphite reflector element from the High-Temperature Test Reactor (HTTR) undergoing machining. Machined parts are assembled to form the core assembly. Figure 3 shows an assembly of prototype parts for the Pebble Bed Modular Reactor-Demonstration Power Plant (PBMR-DPP).

The properties of graphite are a direct consequence of the raw materials used in manufacture and of forming method. A heavy emphasis is placed on the type and source of the coke used in manufacture because the coke's properties largely dictate the properties and behavior of conventionally manufactured graphite. In conventional nuclear graphite, the selection of the coke is paramount. Reactor designers desire isotropic irradiation behavior (to minimize differential irradiation-induced dimensional changes and subsequent stress buildup), and modern nuclear graphites achieve this through a combination of an "isotropic" coke and the forming method. Secondary coke graphites use a nonconventional manufacturing process to achieve the desired isotropic irradiation response and do not depend upon starting with an "isotropic" coke. Essentially, anisotropic cokes are fabricated into graphite and then ground up to become the starting "filler" in a conventional process. Because of the long graphite manufacturing process, the time taken to develop new graphite grades, or introduce a new source of coke, is significant (several years). The importance of the coke type and source is discussed next.

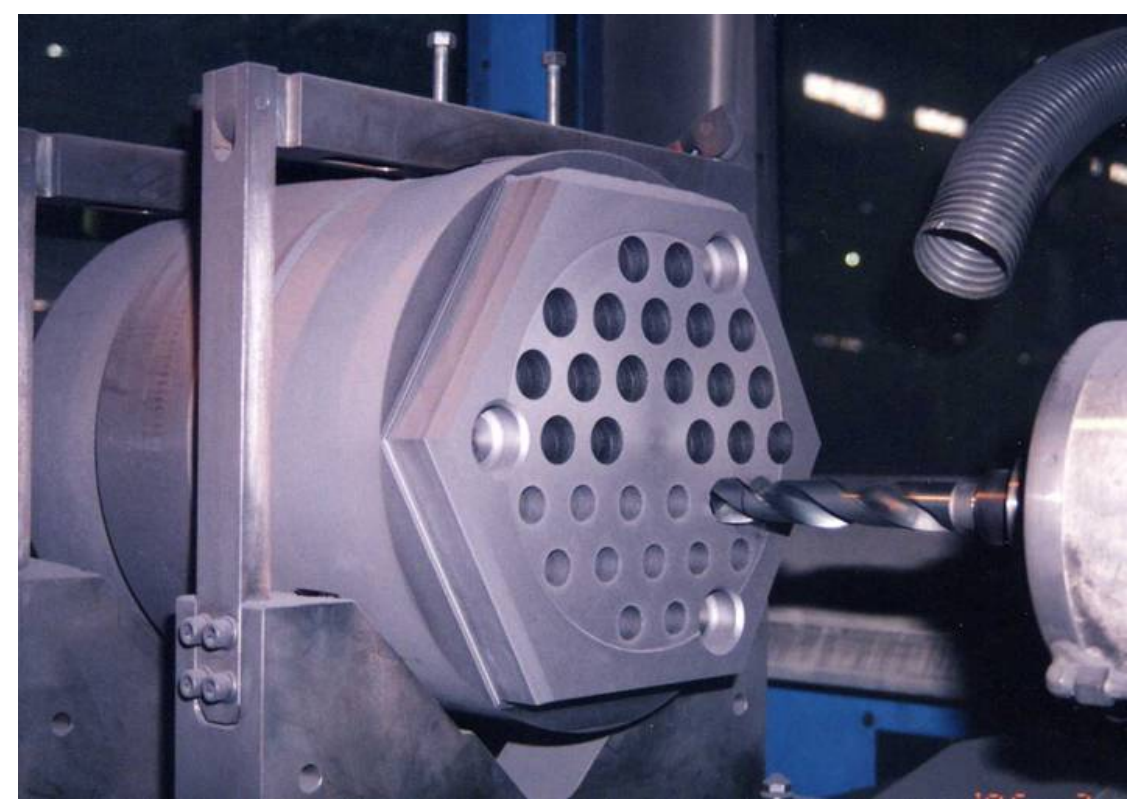

Fig. 2. HTTR graphite reflectors block undergoing machining. ${ }^{1}$ 


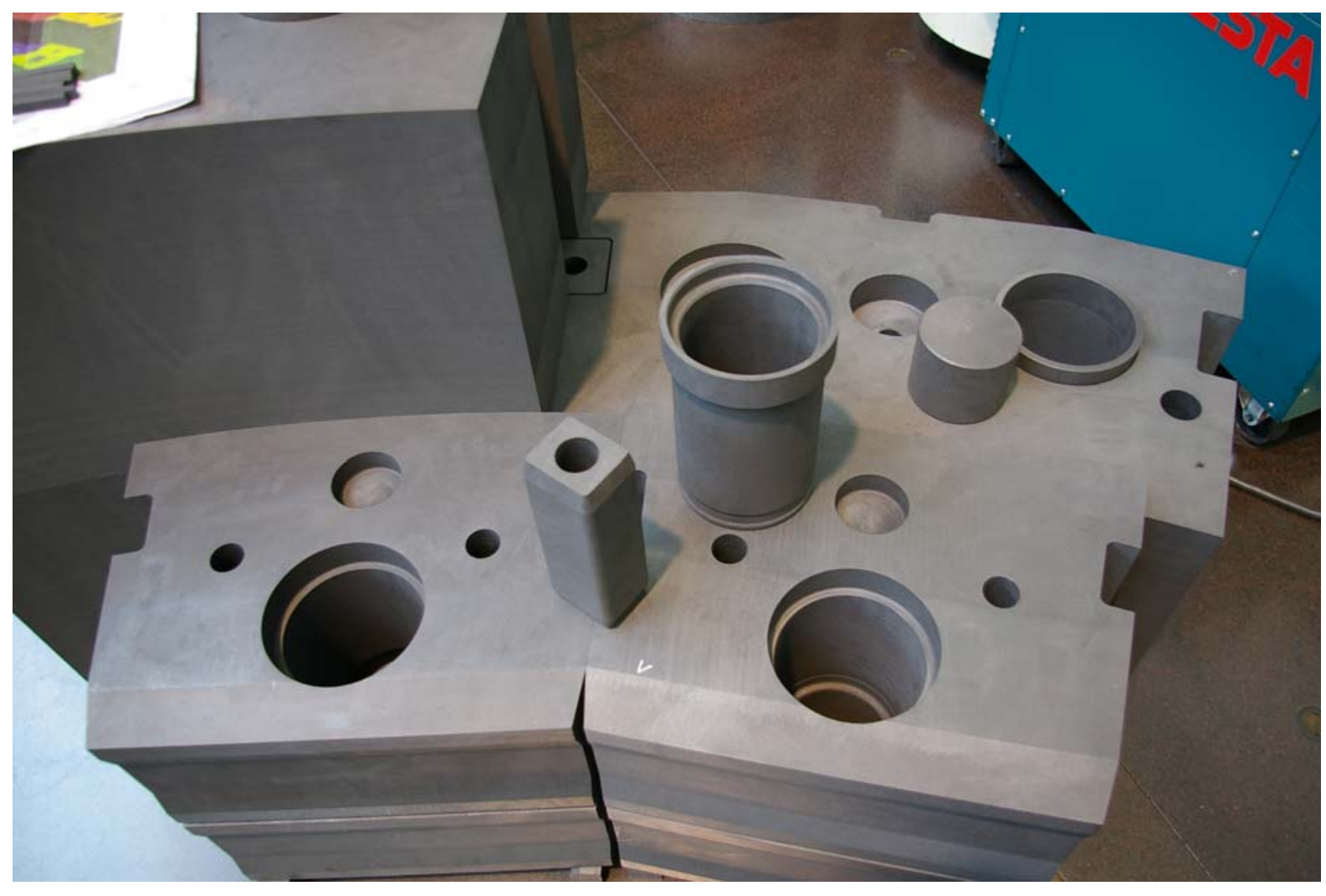

Fig. 3. PBMR DPP test parts assembly. 



\section{NUCLEAR GRAPHITE COKE SOURCES}

Cokes are categorized by their optical texture as observed using polarized light microscopy. An isotropic coke will exhibit an optical texture consisting of small randomly arranged domains (optically isotropic regions) and small pores/cracks, whereas needle cokes have very large optical domains and contain long acicular cracks/pores. The physical appearance and properties of the coke types are therefore very different; needle cokes will exhibit anisotropic properties because the pregraphitic structure is predominantly aligned along the major axis of the coke particle. A graphite body manufactured from a needle coke will typically exhibit large anisotropy in key properties such as coefficient of thermal expansion (CTE), thermal conductivity, and electrical resistivity. This anisotropy is very desirable for arc-furnace electrodes, where low CTE and low electrical resistivity along the major axis of the electrode are preferred. Indeed, the largest tonnage of coke manufactured worldwide is needle coke for electrodes and cathode/anode manufactured to support the steel and aluminum industries, respectively. Graphite with a high degree of anisotropy would not be considered suitable for nuclear applications because the irradiation-induced dimensional changes would also be anisotropic, resulting in high internal stresses, cracking, and shortened irradiation lifetimes. Indeed, early nuclear grades, such as the AGOT graphite, used in the Hanford Piles exhibited such behavior.

Isotropic cokes, by virtue of their structure, lend themselves to forming isotropic, or nearisotropic, graphite. Consequently, isotropic cokes are preferred for the production of modern nucleargrade graphite and other specialty graphites. Isotropic cokes are manufactured from two feedstock sources, oil derivatives (petroleum cokes) and coal tar pitch (pitch cokes).

Petroleum (pet) coke is derived from crude oil. The chemistry of a particular crude source changes over time as the fields are depleted. Oil refineries are run to optimize the production of fuels (petroleum, diesel, etc.); thus, petroleum cokes made from the heavy end of the distillation process will have variable quality and properties dependent on the crude source and refinery operation. By far the largest tonnage of coke made worldwide is petroleum (crude oil distillation) derived needle coke. Certain smaller refineries have developed a niche business supplying high-cost specialty isotropic cokes from sweet light crude (U.S. West Coast). Thus, if a petroleum coke source is selected for the NGNP graphite, the coke is most likely to be produced domestically.

Pitch cokes are made from coal tar, which is produced in a by-product coke oven (by-product coke ovens make metallurgical coke from coal for primary steel making). Two factors are threatening the availability of coal tar pitch and hence pitch cokes, one economic and the other environmental. First, the U.S. primary steel industry has been in decline for the past 30 years; thus, there is a dwindling domestic market for metallurgical cokes. Second, by-product coke ovens are coming under increased environmental pressure to close because they make polluting emissions. Indeed, this forced the closure of such coke ovens in Germany and caused the United Kingdom (U.K.) nuclear industry to switch its pitch coke source to Japan. Current NGNP pitch coke graphite candidates are manufactured from Japanese pitch coke.

Potential NGNP graphite suppliers consider their coke source to be "qualified" for use in graphite for the NGNP. The Japanese source pitch coke has an established pedigree in the nuclear industry, having been the coke source for U.K. Advanced Gas-Cooled Reactor fuel sleeve graphite manufactured by SGL since the mid-1980s. The U.S.-sourced isotropic petroleum-coke has been in production for a long time and has been used for specialty graphite manufacture by GrafTech for many years.

Because there are currently only two isotropic coke sources available, it is recommended that the NGNP project develops an alternative coke source. An alternate source should ideally be politically, geographically, and geologically different from the two sources we currently have, for example, a domestic coal tar pitch source or an overseas source (other than Japan). Several approaches are suggested. Researchers at West Virginia University (U.S.) have developed solvent extraction technology that allows the production of suitable pitch feedstock (from domestic coal) to produce 
isotropic cokes. Note that this production method would be completely different from the current byproduct coke oven route and thus not subject to the same environmental and economic pressures. A second option would be the production of an isotropic coke from an existing coal tar pitch source, such as that available from Sasol, the South African producer of automotive fuels from coal.

Discussions with the University of Pretoria (South Africa) have indicated that there is great interest in developing domestic nuclear graphite for the pebble bed modular reactor (PBMR) market; thus, there are opportunities for collaborative research. An alternate isotropic petroleum coke source could be sought, from a manufacturer other than the current domestic West Coast manufacturer. Finally, graphite, such as the BAN grade from GrafTech, produced via the secondary coke route should be pursued.

A goal of the strategy is to assure graphite for the NGNP by qualifying diverse coke sources and developing alternative coke sources. 


\section{EXISTING CANDIDATE NUCLEAR GRAPHITE GRADES}

The following candidate graphites and historical grades have been identified through discussions with reactor vendors and graphite manufacturers. Candidate graphite materials are presented in Table 1.

Table 1. Graphite selection matrix

\begin{tabular}{|c|c|c|c|c|c|}
\hline Graphite & Manufacturer & $\begin{array}{l}\text { Coke } \\
\text { type }\end{array}$ & $\begin{array}{l}\text { Reactor } \\
\text { vendor }\end{array}$ & Proposed use & Remarks \\
\hline $\mathrm{H}-451$ & SGL & Pet & & & $\begin{array}{l}\text { Historical reference, no } \\
\text { longer available }\end{array}$ \\
\hline IG-110 & Toyo-Tanso & Pet & JAEA/China & $\begin{array}{l}\text { Prismatic fuel element, } \\
\text { replaceable reflector, and } \\
\text { core support pedestals }\end{array}$ & $\begin{array}{l}\text { Historical reference, } \\
\text { currently being used in the } \\
\text { HTTR and HTR-10 }\end{array}$ \\
\hline PCEA & GrafTech & Pet & AREVA & $\begin{array}{l}\text { Prismatic fuel and } \\
\text { replaceable block } \\
\text { Pebble bed reflector and } \\
\text { insulation blocks }\end{array}$ & $\begin{array}{l}\text { AREVA wants to construct } \\
\text { the entire graphite core out } \\
\text { of this graphite, } 0.8-\mathrm{mm} \\
\text { maximum grain size }\end{array}$ \\
\hline NBG-18 & SGL & Pitch & $\begin{array}{l}\text { PBMR/ } \\
\text { AREVA }\end{array}$ & $\begin{array}{l}\text { Prismatic replaceable } \\
\text { reflector } \\
\text { Pebble bed reflector } \\
\text { structure }\end{array}$ & $\begin{array}{l}\text { Candidate for PBMR } \\
\text { replaceable reflector, } \\
1.6-\mathrm{mm} \text { maximum grain } \\
\text { size }\end{array}$ \\
\hline NBG-17 & SGL & Pitch & AREVA & $\begin{array}{l}\text { Prismatic fuel element and } \\
\text { replaceable reflector } \\
\text { Pebble bed reflector } \\
\text { structure and insulation } \\
\text { blocks }\end{array}$ & $\begin{array}{l}\text { AREVA has indicated it } \\
\text { could use a combination of } \\
\text { NBG-17 and NBG-18, } \\
0.8 \text {-mm maximum grain } \\
\text { size. NBG-17 is not } \\
\text { commercially available at } \\
\text { this time }\end{array}$ \\
\hline IG-430 & Toyo-Tanso & Pitch & $\begin{array}{l}\text { JAEA/ } \\
\text { GA }\end{array}$ & $\begin{array}{l}\text { Prismatic fuel element, } \\
\text { replaceable reflector, and } \\
\text { core support pedestals }\end{array}$ & $\begin{array}{l}\text { JAEA wants to use this } \\
\text { graphite in the GTHTR } 300\end{array}$ \\
\hline HLM & SGL & Pet & & $\begin{array}{l}\text { Prismatic large permanent } \\
\text { reflector }\end{array}$ & $\begin{array}{l}\text { Fort St. Vrain permanent } \\
\text { reflector similar to PGX; } \\
\text { GA may use this material }\end{array}$ \\
\hline PGX & GrafTech & Pet & $\begin{array}{l}\text { AREVA } \\
\text { JAEA }\end{array}$ & $\begin{array}{l}\text { Prismatic large permanent } \\
\text { reflector }\end{array}$ & $\begin{array}{l}\text { GA may use this material; } \\
\text { AREVA preference is to use } \\
\text { PCEA or NBG- } 18 \text { for } \\
\text { permanent reflector } \\
\text { HTTR permanent structure }\end{array}$ \\
\hline NBG-25 & SGL & Pet & & Core support candidate & Isostatic fine grain \\
\hline 2020 & $\begin{array}{l}\text { Carbone of } \\
\text { America }\end{array}$ & Pet & GA & $\begin{array}{l}\text { Prismatic fuel element, } \\
\text { replaceable reflector, and } \\
\text { core support pedestals }\end{array}$ & $\begin{array}{l}\text { Fine-grain isotropic, } \\
\text { candidate material }\end{array}$ \\
\hline
\end{tabular}


Table 1. (continued)

\begin{tabular}{|c|c|c|c|c|c|}
\hline Graphite & Manufacturer & $\begin{array}{l}\text { Coke } \\
\text { type }\end{array}$ & $\begin{array}{l}\text { Reactor } \\
\text { vendor }\end{array}$ & Proposed use & Remarks \\
\hline PCIB & GrafTech & Pet & & Core support candidate & Fine-grain isotropic \\
\hline BAN & GrafTech & $\begin{array}{l}\text { Secondary/ } \\
\text { needle } \\
\text { (pet) }\end{array}$ & & & $\begin{array}{l}\text { Secondary coke experimental } \\
\text { graphite that offers a route } \\
\text { to a diverse coke source }\end{array}$ \\
\hline \multirow[t]{2}{*}{ NBG-10 } & & & PBMR & $\begin{array}{l}\text { Prismatic fuel element and } \\
\text { replaceable reflector }\end{array}$ & $\begin{array}{l}\text { PBMR's original choice for } \\
\text { replaceable reflector. }\end{array}$ \\
\hline & & & & $\begin{array}{l}\text { Pebble bed reflector } \\
\text { structure and insulation } \\
\text { blocks }\end{array}$ & $\begin{array}{l}\text { Subsequently replaced by } \\
\text { NBG-18, based on } \\
\text { price/performance }\end{array}$ \\
\hline 2191 & & & GA & $\begin{array}{l}\text { Prismatic fuel element, } \\
\text { replaceable reflector, and } \\
\text { core support pedestals }\end{array}$ & $\begin{array}{l}\text { Fine-grain isotropic, } \\
\text { candidate material }\end{array}$ \\
\hline
\end{tabular}




\section{FACTORS INFLUENCING GRAPHITE SELECTION FOR THE NGNP}

\subsection{GRAPHITE VENDORS' POSITION}

Four potential manufacturers have been identified. NGNP project staff met with two of the potential vendors (GrafTech and SGL) earlier in FY 2007. Both companies expressed a desire to be the graphite vendor for the NGNP and can supply production billets in "lot" quantities.

\subsubsection{GrafTech}

GrafTech reported that it had made a business decision to switch future production of PCEA graphite from the Notre Dame (France) plant to the United States (Clarksburg, WV). Consequently, the NGNP project should purchase a "lot" (>10 billets), to be made at WV, and demonstrate this is similar to the prior production PCEA made in France. The WV plant should also be NQA-1 qualified prior to production of new nuclear-grade graphite.

\subsubsection{SGL}

Graphite NBG-18 has been in continuous production at SGL's plants for the past 12-18 months for PBMR. Billets are available for purchase that were produced in accordance with PBMR specification and quality assurance (QA) plan, and would thus be considered as qualified by PBMR. However, the size available is smaller than the standard PBMR block because they are from an early production lot. Consequently, a "lot" of NBG-18 billets with dimensions $500 \times 540 \times 1900 \mathrm{~mm}$ should be purchased to support the NGNP project. Grade NBG-17 is not available in either large blocks (to meet PBMR size requirements) or large quantities (because of incomplete in-house commercial development at SGL). If NGNP wants to use this grade, funding would have to be provided to SGL to finish commercial development. The SGL European plants should also be NQA-1 qualified prior to production of NGNP nuclear-grade graphite.

\subsubsection{Toyo Tanso}

The two Japanese grades under consideration (Toyo Tanso's IG-110 and IG-430) are in continuous production. The Japan Atomic Energy Agency (JAEA) considers IG-430 as the candidate for future very high-temperature reactor (VHTR) projects in Japan.

\subsubsection{Carbone of America}

Carbone of America has offered grade 2191 graphite as a potential alternate to grade 2020. Both 2020 and 2191 are alternates to the fine-grained, isostatically molded Toyo Tanso grades IG-110 and IG-430.

\subsection{GRAPHITE SELECTION TRADE-OFFS}

As noted above, the reactor type (pebble bed or prismatic block) has a major influence on the designer's selection of graphite. The core blocks (central and outer reflector) of a pebble bed reactor are core lifetime components, ideally with a life of $>50$ years. However, the neutron dose received by the pebble bed-facing central and outer reflector blocks is large, and they will require replacement before the end of reactor life. The replacement timing cannot be predicted with certainty because of the inaccuracy of the current graphite dimensional change and creep models. However, replacement will be required when the pebble bed-facing graphite component's irradiation-induced dimensional 
changes become excessive (rapid expansion after volume turnaround), after approximately 15-20 full-power years of operation. Thus, the PBMR designers had to select graphite that had good dimensional stability and a long irradiation lifetime (i.e., near-isotropic graphite). More expensive graphite could be entertained if it had demonstrated advantages of dimensional change isotropy, which would allow longer irradiation lifetimes and longer intervals between core block replacements. Moreover, because the pebble bed-facing components cannot easily be replaced, the designer will require the blocks to be of the highest possible quality and free from internal defects that might cause premature failure in service. Fewer core block replacements give the reactor owner/operator less graphite to dispose of over the life of the plant and at decommissioning.

In contrast, a prismatic block reactor discharges fuel blocks and replaceable reflector blocks before they accumulate excessive neutron damage. Thus, irradiation lifetime is less of a concern than in the pebble bed reactor. However, the designer may still require isotropic dimensional change response and must know the creep behavior of the graphite to assure that the fine graphite webs between the fuel and coolant channels do not fail. Moreover, these fine webs (only a few millimeters in thickness) dictate the use of reasonably fine grain graphite ( $<1-\mathrm{mm}$ maximum filler particle size). In the case of the HTTR, very fine grained graphite was adopted-IG-110 ( 20- $\mu \mathrm{m}$ grain size). The designer may consider the strength of the graphite to be a major consideration given the small dimensions of the fuel/coolant channel webs. The use of fine-grained graphite will place constraints on the sizes of the graphite block that can be produced. Thus, the permanent core structure must be a different grade (typically with a larger grain size) than the fuel element graphite. Over the lifetime of the plant a large number of graphite blocks (fuel elements and replaceable reflector blocks) will be discharged for disposal. For this reason some designers have considered the reuse of fuel elements as one option to limit the number of blocks for disposal. A workable fuel discharge procedure/method must be established to enable this. Moreover, the neutron damage dose received by the reused blocks is doubled, and thus the "lifetime" of the graphite becomes more of a consideration. In the Japanese HTTR fuel element design, the fuel channels are relatively large and accept a graphite cylinder containing the fuel compacts (a fuel pin). The fuel pins are thus relatively easily discharged and replaced, and the graphite fuel element reused. The potential reuse of graphite fuel elements may lessen the designer's sensitivity to the cost of the graphite. Isostatically molded fine grain graphites are more expensive than their extruded counterparts, but require less characterization; thus, the scope and cost of the TDP may be reduced over that required for and extruded graphite. However, the scope and cost of the irradiation program would be markedly increased because of the need for longer duration irradiation experiments.

The cost of graphite for replaceable reflectors and fuel elements is a large and significant fraction of the lifetime operational costs of a reactor. Consequently, the designer may wish to minimize the cost of the selected graphite or maximize the duty cycle. The first option may require a trade-off in properties (notably, lower strength and increased variability in properties), and the latter option may present technical challenges in the refueling process. One prismatic core designer (AREVA), has indicated a preference to reuse the fuel elements and increase the duty cycle of the replaceable reflectors. As noted above, such a course of action increases the scope and cost of the TDP because longer duration materials test irradiations would be required. In the pebble bed design the graphite structure is considered permanent, although there is an expectation that certain high neutron dose components (pebble bed-facing blocks of the central and outer reflector) will be replaced during the lifetime of the reactor.

Graphite removed from the reactor must be disposed of, and this represents a significant cost. Consequently, reducing the amount of graphite sent to disposal or storage, for example, by increasing the fuel element and replaceable reflector duty cycle, is attractive. The cost and volume of graphite disposal is also the driving force behind consideration of a graphite recycle option. Discharged graphite could be taken to a dedicated facility, ground into powder, and annealed $\left(\sim 3000^{\circ} \mathrm{C}\right)$ at high temperature with the activity being captured. The graphite could then be reconstituted into new billets, or used as an additive in the production of new billets. This option must be considered as a 
long-term strategy, and considerable research would be required into graphite fabrication from graphitized feedstock, although such graphite fabrication methods have been employed before (e.g., BAN graphite).

Here we assume that the NGNP will seek a reactor demonstration license, thus requiring frequent outages for fuel performance assessment and core inspection. If this licensing approach is pursued, less graphite data will be needed to support initial licensing, allowing more time to acquire the materials test reactor data and potentially develop new or alternate grades of graphite (or coke sources). The recent U.S. Nuclear Regulatory Commission "Phenomena Identification and Ranking Table" (PIRT) exercise for graphite 4 identified a number of data deficiencies that will need to be addressed in the NGNP graphite TDP and that may impact the NGNP licensing strategy.

The PBMR licensing strategy is to compensate for uncertainty in graphite behavior as the graphite begins to accumulate damage with an appropriate in-service inspection (ISI) program. Such a strategy delays the need for data from high-dose irradiation experiments and thus buys additional time for the technology development and materials test reactor (MTR) programs. Consideration should be given to a defense-in-depth approach such that in parallel with the MTR program NGNP should develop ISI and nondestructive examination techniques for graphite reflector blocks.

Several graphite grades have been identified through discussions with Gen IV partners and graphite vendors as potential candidates for the NGNP (Table 1). The grades selected by reactor vendors are discussed in Sect. 6. In addition to graphite availability, the existence of a design database must be considered. The majority of the suitable graphites currently in existence do not have large irradiation databases available. Data are available from the HTTR program in Japan for IG-110. Irradiation programs are ongoing in the United States and European Union to generate data for certain candidate grades. Consideration should be given to including additional graphites in the MTR program (as alternates) where their inclusion has direct benefit to the technology program (e.g., for comparison of filler cokes or forming method). 



\section{CURRENT REACTOR VENDORS' POSITION(S)}

\subsection{AREVA}

AREVA has proposed two graphite options for its reactor design: (1) whole core of PCEA or (2) a mix of NBG-17 and NBG-18. The graphite used for the prismatic fuel element must have a sufficiently small grain size to allow for the machining of the fuel and coolant channels. Both PCEA and NBG-17 have a maximum grain size of $0.8 \mathrm{~mm}$, whereas NGB-18 has a maximum grain size of $1.6 \mathrm{~mm}$. Thus, to cover both AREVA core design options we should include PCEA and NBG-18/NBG-17 as alternates.

\subsection{GENERAL ATOMICS (GA)}

GA has indicated that it is considering a fine-grain isotropic grade for the fuel element, replaceable reflector, and core support structure, in its NGNP design, for example, Toyo Tanso grades IG-110 and IG-430. Recently, GA has held discussions with Carbone of America regarding the suitability of grades for its NGNP design. Carbone of America identified several grades $(2020,2191$, 2114, and 2160) as reported below.

Table 2. Candidate Carbone of America graphite grades ${ }^{5}$

\begin{tabular}{|c|c|c|c|c|}
\hline Grade & Description & Coke type & $\begin{array}{c}\text { CTE } \\
\text { isotropy } \\
\text { ratio }\end{array}$ & $\begin{array}{l}\text { Block size } \\
\quad(\mathbf{m m})\end{array}$ \\
\hline 2020 & Fine grained, isotropic & Petroleum coke & 1.14 & $\begin{array}{l}914 \text { diam } \times 762 \\
305 \times 1016 \times 1016 \\
508 \times 610 \times 1829\end{array}$ \\
\hline 2191 & Super fine grained, isotropic & $\begin{array}{l}\text { Petroleum (sponge) } \\
\text { coke }\end{array}$ & 1.2 & $\begin{array}{l}610 \text { diam } \times 1829 \\
546 \times 1829\end{array}$ \\
\hline 2114 & Super fine grained, isotropic & Nonpetroleum coke & 1.04 & $305 \times 610 \times 1829$ \\
\hline 2160 & Ultra fine grained, isotropic & Nonpetroleum coke & 1.06 & $330 \times 330 \times 914$ \\
\hline
\end{tabular}

Based upon the Carbone of America's data (Table 2), only grades 2020 and 2191 are manufactured in blocks large enough to support the prismatic design. The isotropy ratio of grade 2191 exceeds the requirement for near-isotropic nuclear graphite (CTE ratio < 1.15). ${ }^{6}$ Consequently, grade 2020 would appear to be the only viable candidate from Carbone of America. In previous GA prismatic block designs, large graphite blocks were required for the permanent outer reflector structure. Consequently, PGX should be included in the NGNP graphite TDP. The HTTR also utilizes PGX for its permanent reflector structure.

\subsection{PBMR}

The PBMR design utilizes NBG-18 for all core components. Indeed, PBMR has already purchased the NBG-18 graphite for the demonstration power plant (DPP), and it is currently being machined in Germany. PBMR is planning to initiate an MTR program in the near future. 



\section{RECOMMENDED NGNP GRAPHITE SELECTION AND ACQUISITION STRATEGY}

It is recommended that the following six graphites be considered as candidates for the NGNP: GrafTech's PCEA and PGX; SGL's NBG-18 and NBG-17; Toyo Tanso's IG-430; and Carbone of America's 2020 (Table 3).

Table 3. Graphites recommended for inclusion in the NGNP Graphite Technology Development Program

\begin{tabular}{llll}
\hline Grade & \multicolumn{1}{c}{ Manufacturer } & Coke type & \multicolumn{1}{c}{ Comments } \\
\hline IG-430 & Toyo Tanso & Pitch coke & $\begin{array}{c}\text { Isostatically molded, candidate for high-dose } \\
\text { regions of NGNP concepts } \\
\text { Vibrationally molded, candidate for high-dose } \\
\text { regions of NGNP prismatic core concepts (not } \\
\text { currently commercially available) }\end{array}$ \\
NBG-18 & SGL & Pitch coke & $\begin{array}{c}\text { Vibrationally molded, candidate for high-dose } \\
\text { regions of NGNP pebble bed concepts; PBMR } \\
\text { reflector graphite }\end{array}$ \\
PCEA & GrafTech International & Petroleum coke & $\begin{array}{c}\text { Extruded, candidate for high-dose regions of } \\
\text { NGNP prismatic core concepts }\end{array}$ \\
PGX & GrafTech International & Petroleum coke & $\begin{array}{c}\text { Large blocks for permanent structure in a } \\
\text { prismatic core (used in HTTR) }\end{array}$ \\
\hline
\end{tabular}

If a pebble bed reactor concept were selected for the NGNP, the candidate graphites would drop to one, that is, NBG-18. Moreover, technology development costs could be leveraged with those being performed in support of PBMR's DPP. If however a prismatic block reactor is selected, the situation is more complex. Carrying both prismatic options, as we currently understand the NGNP consortium and reactor vendor's positions, would require all six graphites to be included in the program. Selection of just one prismatic block reactor vendor would drop the number of candidates to three grades. Because the NGNP concept and vendor are unknown at this time, we have to include all six grades in the program. Unfortunately, funding is constrained. Consequently, we must prioritize the technology development effort. Grades NBG-18 and PCEA will satisfy all needs but may not be a particular reactor vendor's first choice of graphite. Thus, our major grades should be PCEA and NBG-18, and we should add the other four grades only when funding becomes available or if a specific NGNP vendor is chosen.

Production-size "lots" of grades NBG-18 and PCEA should be purchased for inclusion in the NGNP irradiation program and for subsequent characterization. Full qualification will require the acquisition of multiple lots over a period of several years. A sufficient quantity of graphite has already been acquired to meet our irradiation specimen needs (AGC-1 creep experiment) for the four alternate grades (NBG-17, IG 430, PGX, and 2020).

The schedule for the acquisition, qualification, and irradiation of graphite must be fully integrated with the NGNP schedule. It is estimated to take a minimum of 3 years to manufacture and machine all the graphite for the first NGNP core. The two largest graphite manufacturers (SGL and GrafTech) have the capability to supply NGNP on this schedule but may wish to add a dedicated machine shop and core assembly area. However, before such a purchase could be made an initial qualification program involving several 'lots' of the selected candidate(s) and an irradiation program must be 
conducted. ${ }^{2}$ The initial qualification program would be $\sim 10$ years in length, and a complete irradiation program would require $>15$ years. The exact duration of the qualification and irradiation program obviously depend upon the reactor concept selected and the number of graphites included in the qualification program. Also, as previously discussed, the licensing strategy adopted for NGNP will influence the duration and scope of the irradiation program. Acquisition and machining of NGNP core graphite prior to the completion of the technology development program carries an inherent risk. However, the NGNP design team may wish, in the interest of schedule, to accept this risk. Table 4 summarizes the factors influencing the graphite selection and acquisition strategy.

In summary, the following actions are strongly recommended:

- qualify two graphite vendors (SGL \& GrafTech International) to NQA-1,

- purchase production lots of PCEA and NBG-18 from above vendors,

- begin characterization of the properties of the above two major candidate grades,

- continue irradiation experiments with two major graphites (NBG-18 and PCEA) and other alternates (IG-430, NBG-17, 2020, and PGX) until more definition on the NGNP design and vendor is available, and

- pursue collaboration with international partners via Gen IV.

Furthermore, it is recommended that

- serious consideration be given to establishing alternative coke sources to the two currently available (U.S. pet coke and Japanese pitch coke), and

- explore graphite recycle and reuse options. 
Table 4. Graphite strategy advantages and disadvantages for each reactor vendor's NGNP design

\begin{tabular}{|c|c|c|c|c|c|c|}
\hline \multirow{2}{*}{ Criteria } & \multicolumn{2}{|c|}{ W/PBMR } & \multicolumn{2}{|c|}{ AREVA } & \multicolumn{2}{|c|}{ GA } \\
\hline & Advantage & Disadvantage & Advantage & Disadvantage & Advantage & Disadvantage \\
\hline Number of graphites & $\begin{array}{l}\text { Design more mature } \\
\text { and have down- } \\
\text { selected to } \\
\text { NBG-18 only, thus } \\
\text { reduced scope of } \\
\text { TDP }\end{array}$ & $\begin{array}{l}\text { No diversity of } \\
\text { supply }\end{array}$ & $\begin{array}{l}\text { Two: PCEA and } \\
\text { NGB-17 for fuel } \\
\text { blocks, and } \\
\text { NBG-18 as a } \\
\text { possible grade for } \\
\text { the permanent } \\
\text { reflector }\end{array}$ & $\begin{array}{l}\text { Increased scope of } \\
\text { TDP; cannot use } \\
\text { the same graphite } \\
\text { for entire core }\end{array}$ & $\begin{array}{l}\text { GA position not } \\
\text { currently well } \\
\text { defined. Possibly } \\
\text { using isostatically } \\
\text { molded grades } \\
\text { (two sources), thus } \\
\text { supplier diversity } \\
\text { achieved }\end{array}$ & $\begin{array}{l}\text { Cannot use the same } \\
\text { graphite for entire } \\
\text { core; will require } \\
\text { additional grade for } \\
\text { the large perma- } \\
\text { nent reflector } \\
\text { blocks, thus } \\
\text { expanding the } \\
\text { scope of the TDP }\end{array}$ \\
\hline $\begin{array}{l}\text { Maturity of database; } \\
\text { amount/difficulty in } \\
\text { qualification }\end{array}$ & $\begin{array}{l}\text { An entire core of } \\
\text { graphite is in } \\
\text { production, and } \\
\text { shall be } \\
\text { characterized by } \\
\text { SGL/PBMR. Data } \\
\text { available through } \\
\text { collaboration. } \\
\text { Similarly, PBMR } \\
\text { planning MTR } \\
\text { program offering } \\
\text { NGNP leveraging } \\
\text { opportunity }\end{array}$ & $\begin{array}{l}\text { Pebble bed } \\
\text { moderator block } \\
\text { will experience } \\
\text { very large neutron } \\
\text { dose; thus, MTR } \\
\text { experiments are of } \\
\text { longer duration and } \\
\text { have increased } \\
\text { design and } \\
\text { operational } \\
\text { complexity }\end{array}$ & $\begin{array}{l}\text { Prismatic reactor } \\
\text { has smaller neutron } \\
\text { dose to graphite } \\
\text { components, hence } \\
\text { shorter MTR } \\
\text { program, but could } \\
\text { require tensile } \\
\text { creep testing if } \\
\text { higher than 7-dpa } \\
\text { dose is desired }\end{array}$ & $\begin{array}{l}\text { Little or no data for } \\
\text { NBG-17 or PCEA } \\
\text { (only EU } \\
\text { preliminary data) }\end{array}$ & $\begin{array}{l}\text { Prismatic reactor } \\
\text { has smaller neutron } \\
\text { dose to graphite } \\
\text { components, hence } \\
\text { shorter MTR } \\
\text { program. Data } \\
\text { available for } \\
\text { IG-110 from HTR } \\
\text { program (Japan); } \\
\text { EU program } \\
\text { includes IG-430 }\end{array}$ & $\begin{array}{l}\text { No data available } \\
\text { for Carbone USA } \\
\text { candidate }\end{array}$ \\
\hline $\begin{array}{l}\text { Performance expected by } \\
\text { vendor }\end{array}$ & $\begin{array}{l}\text { Vendor expects } \\
>15 \text { full-power } \\
\text { years before } \\
\text { changeout } \\
\text { required. Limited } \\
\text { historical data or } \\
\text { confirmatory data } \\
\text { exist to support } \\
\text { vendor's } \\
\text { expectations } \\
\end{array}$ & $\begin{array}{l}\text { Replacement of } \\
\text { pebble-facing } \\
\text { graphite } \\
\text { components will } \\
\text { require prolonged } \\
\text { outage }\end{array}$ & $\begin{array}{l}\text { Fuel block graphite } \\
\text { expected to be } \\
\text { adequate for one } \\
\text { cycle. Site dose } \\
\text { range for one } \\
\text { cycle; extended } \\
\text { cycle would } \\
\text { require additional } \\
\text { irradiation testing }\end{array}$ & $\begin{array}{l}\text { Fuel block reuse has } \\
\text { to be demonstrated }\end{array}$ & $\begin{array}{l}\text { Fuel block graphite } \\
\text { expected to be } \\
\text { adequate for one } \\
\text { cycle }\end{array}$ & $\begin{array}{c}\text { Fuel block reuse has } \\
\text { to be demonstrated }\end{array}$ \\
\hline
\end{tabular}


Table 4. (continued)

\begin{tabular}{|c|c|c|c|c|c|c|}
\hline \multirow{2}{*}{ Criteria } & \multicolumn{2}{|c|}{ W/PBMR } & \multicolumn{2}{|c|}{ AREVA } & \multicolumn{2}{|c|}{ GA } \\
\hline & Advantage & Disadvantage & Advantage & Disadvantage & Advantage & Disadvantage \\
\hline Waste & $\begin{array}{l}\text { Less waste core } \\
\text { graphite generated } \\
\text { (not including fuel } \\
\text { pebbles) }\end{array}$ & & & $\begin{array}{l}\text { Large volume of } \\
\text { core graphite } \\
\text { waste. Refueling } \\
\text { graphite blocks is } \\
\text { technically } \\
\text { challenging }\end{array}$ & & $\begin{array}{l}\text { Large volume of } \\
\text { core graphite } \\
\text { waste. Refueling } \\
\text { graphite blocks is } \\
\text { technically } \\
\text { challenging }\end{array}$ \\
\hline $\begin{array}{l}\text { Relative complexity and } \\
\text { scope of the TDP }\end{array}$ & \multicolumn{2}{|c|}{$\begin{array}{l}\text { Selection of single graphite reduces the } \\
\text { scope of the TDP }\end{array}$} & \multicolumn{2}{|c|}{ Increased } & \multicolumn{2}{|c|}{ Increased } \\
\hline $\begin{array}{l}\text { Relative duration of the } \\
\text { irradiation program }\end{array}$ & \multicolumn{2}{|c|}{$\begin{array}{c}\text { Increased (but maybe able to leverage } \\
\text { PBMR program) }\end{array}$} & \multicolumn{2}{|c|}{$\begin{array}{l}\text { Reduced, unless fuel } \\
\text { blocks are reused }\end{array}$} & \multicolumn{2}{|c|}{$\begin{array}{l}\text { Reduced, unless fuel } \\
\text { blocks are reused }\end{array}$} \\
\hline
\end{tabular}




\section{REFERENCES}

1. R. Bratton, NGNP Graphite Selection Strategy, INL/EXT-05-00269 (May 2005).

2. W. Windes, T. Burchell, and R. Bratton, NGNP Graphite Technology Development Plan, Idaho National Laboratory (2007).

3. T. Burchell, Carbon Materials for Advanced Technologies, Chap. 13, "Fission Reactor Applications," Elsevier Science (1999).

4. T. Burchell, et al., Next-Generation Nuclear Plant Phenomena Identification and Ranking Tables (PIRTs)_Volume 5: Graphite PIRTs (NUREG/CR-6944, Vol. 5), ORNL/ TM-2007/147, Vol. 5, Oak Ridge National Laboratory.

5. Presentation by Carbon Lorraine to General Atomics, "Carbone Graphite Grades" (2007).

6. ASTM D7219-05, "Standard Specification for Isotropic and Near-Isotropic Nuclear Graphites,” ASTM International, U.S.A. (2005). 



\section{INTERNAL DISTRIBUTION}
1. T. D. Burchell
2. W. R. Corwin
3. S. R. Greene
4. D. T. Ingersoll
5. Y. Katoh
6. J. W. Klett
7. E. Lara-Curzio
8. C. R. Luttrell
9. L. K. Mansur
10. R. K. Nanstad
11. W. Ren

\author{
12. P. L. Rittenhouse \\ 13. A. F. Rowcliff \\ 14. L. L. Snead \\ 15. R. G. Stoller \\ 16. R. W. Swindeman \\ 17. P. F. Tortorelli \\ 18. B. J. Waddell \\ 19. D. F. Wilson \\ 20. S. J. Zinkle \\ 21. ORNL Laboratory Records (RC)
}

\section{EXTERNAL DISTRIBUTION}

22. C. Barnard, Idaho National Engineering and Environmental Laboratory, P.O. Box 1625, Idaho Falls, Idaho 83415-3750

23. R. Bratton, Idaho National Engineering and Environmental Laboratory, P.O. Box 1625, Idaho Falls, Idaho 83415-3750

24. T. Cook, NE-20/Germantown Building, Office of Advanced Nuclear Research, U.S. Department of Energy, 1000 Independence Avenue, S.W., Washington, DC 20585-1290

25. D. Petti, Idaho National Engineering and Environmental Laboratory, P.O. Box 1625, Idaho Falls, Idaho 83415-3750

26. T. J. O'Conner, NE-20/Germantown Building, Office of Advanced Nuclear Research, U.S. Department of Energy, 1000 Independence Avenue, S.W., Washington, DC 20585-1290

27. R. Soto, Idaho National Engineering and Environmental Laboratory, P.O. Box 1625, Idaho Falls, Idaho 83415-3750

28. R. Versluis, NE-20/Germantown Building, Office of Advanced Nuclear Research, U.S. Department of Energy, 1000 Independence Avenue, S.W., Washington, DC 20585-1290

29, K. Weaver, Idaho National Engineering and Environmental Laboratory, P.O. Box 1625, Idaho Falls, Idaho 83415-3750

30. W. Windes, Idaho National Engineering and Environmental Laboratory, P.O. Box 1625, Idaho Falls, Idaho 83415-3750 